\title{
Atypical fibroxanthoma in a young woman: An unusual case presentation
}

\author{
Mark M Melendez MD MBA ${ }^{1}$, Xiaoti Xu BS ${ }^{2}$, Steve A McClain MD³ , Su-I Daniel Huang MD ${ }^{4}$
}

MM Melendez, X Xu, SA McClain, S-ID Huang. Atypical fibroxanthoma in a young woman: An unusual case presentation. Can J Plast Surg 2007;15(3):169-172.

Atypical fibroxanthoma (AFX) is an uncommon neoplasm, identified as a spindle cell tumour that is generally found in elderly patients on sun-exposed areas. The majority of cases of AFX are benign, and metastasis is a rare phenomenon. The first case in the literature of AFX is described in a young woman with no previous risk factors who presented with a three-month history of an enlarging nodule of the left nasal alar. Excision showed the lesion to be composed of hyperchromatic, pleomorphic, vacuolated spindle cells and multinucleated giant cells. The tumour cells stained positive for macrophage-histiocyte antigen alpha ${ }_{1}$-antitrypsin, neurokinin-1, CD68 and alpha ${ }_{1}$-antichymotrypsin. The present case report highlights the importance of correct diagnosis for AFX with adequate excision and by considering the histopathology and immunohistochemistry of its clinical differential diagnosis.

Key Words: Atypical fibroxanthoma; Histopathology; Immunohistochemistry; Mohs micrographic surgery

$\Delta$ typical fibroxanthoma (AFX) is a spindle cell tumour that $A_{\text {was first characterized in } 1963 \text { by Helwig (1). Despite the }}$ presence of bizarre xanthoma cells giving rise to the name, AFX was initially described as a benign reactive process. However, once reports of metastasis appeared, the malignant potential of this low-grade form of malignant fibrous histiocytoma was recognized (2). AFX is an uncommon neoplasm that is generally found in elderly Caucasian men with sun-damaged skin, yet there is a second peak in young adults (3). In our search of the literature, the average age of patients diagnosed with AFX was 69 years, with a male to female ratio of $2: 1$. AFX arising in young adults tends to occur on the limbs and trunk, with a mean age of 44 years (4-6).

AFX typically begins as a solitary firm erythematous nodule that grows rapidly and may become ulcerated (7). Most lesions tend to be smaller than $2 \mathrm{~cm}$, although lesions larger than $10 \mathrm{~cm}$ have been reported (4). Despite the malignant appearance histopathologically, AFX generally follows a benign clinical course; they rarely metastasize (2). Clinically, AFX resembles other cutaneous and superficial soft tissue tumours, including squamous cell carcinoma, basal cell carcinoma, malignant melanoma, malignant fibrous histiocytoma and neurothekeoma. Histopathologically, hematoxylin and eosin stains generally do not permit distinction from the spindle cell forms of malignant melanoma, squamous cell carcinoma or

\section{Un fibroxanthome atypique chez une jeune femme : Une présentation de cas inhabituelle}

\begin{abstract}
Le fibroxanthome atypique (FXA) est un néoplasme peu courant qui prend la forme de tumeur fusocellulaire généralement observée sur la peau exposée au soleil de personnes âgées. La majorité des cas de FXA sont bénins, et les métastases sont rares. Le premier cas de FXA publié est décrit chez une jeune femme sans facteur de risque préalable qui a consulté à cause de l'hypertrophie d'un nodule sur l'aile gauche du nez depuis trois mois. L'excision a révélé que la lésion se composait de cellules fusocellulaires hyperchromatiques, polymorphes et vacuolantes et de cellules géantes nucléées. La coloration des cellules tumorales était pos-

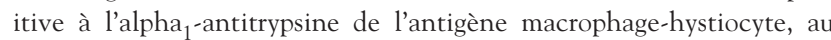

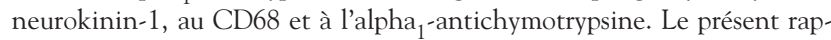
port de cas souligne l'importance de bien diagnostiquer le FXA au moyen d'une excision adéquate et de l'évaluation de l'histopathologie et de l'immunocytochimie du diagnostic différentiel clinique.
\end{abstract}

\footnotetext{
${ }^{1}$ Department of Surgery; ${ }^{2}$ School of Medicine, ${ }^{3}$ Department of Pathology, Stony Brook University Medical Center, State University of New York at Stony Brook, Stony Brook; ${ }^{4}$ Department of Surgery, Division of Plastic and Reconstructive Surgery, Northport Veterans Affairs Medical Center, Northport, New York, USA

Correspondence and reprints: Dr Mark M Melendez, Department of Surgery, Stony Brook University Medical Center, HSC, Level 19,

Room 067, Stony Brook, New York 11794-8191, USA. Telephone 631-444-7893, fax 631-444-6176, e-mail mark.melendez@sunysb.edu
} 
TABLE 1

Histopathology for the clinical differential diagnosis of atypical fibroxanthoma

\begin{tabular}{|c|c|}
\hline $\begin{array}{l}\text { Clinical differential } \\
\text { diagnosis }\end{array}$ & Histopathology \\
\hline $\begin{array}{l}\text { Atypical } \\
\text { fibroxanthoma }\end{array}$ & $\begin{array}{l}\text { Rapidly growing, well-circumscribed in dermis } \\
\text { to subcutaneous tissue; bizarre spindle cells; } \\
\text { giant cells; multinucleated xanthomatous cells; } \\
\text { no true primary epidermal involvement }\end{array}$ \\
\hline Leiomyosarcoma & $\begin{array}{l}\text { Eosinophilic cytoplasm; blunt-ended spindle } \\
\text { nuclei; perinuclear vacuoles; mitotic figures }\end{array}$ \\
\hline $\begin{array}{l}\text { Malignant fibrous } \\
\text { histiocytoma }\end{array}$ & $\begin{array}{l}\text { Storiform-pleomorphic form,; plump spindle cells } \\
\text { arranged in short fascicles around slit-like } \\
\text { vessels; bizarre cells - eosinophilic } \\
\text { to xanthomatous }\end{array}$ \\
\hline Melanoma & $\begin{array}{l}\text { Nests and/or fascicles of large spindle } \\
\text { melanocytes; asymmetry of architecture }\end{array}$ \\
\hline $\begin{array}{l}\text { Squamous cell } \\
\text { carcinoma }\end{array}$ & $\begin{array}{l}\text { Well-differentiated; variable degree of } \\
\text { atypia; primary epidermal involvement }\end{array}$ \\
\hline $\begin{array}{l}\text { Basal cell } \\
\text { carcinoma }\end{array}$ & $\begin{array}{l}\text { Lobulated appearance; small keratinocytes; } \\
\text { outer layer of palisade larger cells; mitotic } \\
\text { figures; multiple small tumour lobules }\end{array}$ \\
\hline $\begin{array}{l}\text { Dermatofibroma } \\
\text { with monster cells }\end{array}$ & $\begin{array}{l}\text { Circumscribed; epidermal hyperplasia,; large, } \\
\text { multinucleated histiocytes; mitotic figures }\end{array}$ \\
\hline $\begin{array}{l}\text { Neurothekeoma } \\
\text { (nerve sheath myxoma) }\end{array}$ & $\begin{array}{l}\text { Distinct lobules by fibrous connective tissue; } \\
\text { pleomorphism; few mitotic figures; benign } \\
\text { giant cells }\end{array}$ \\
\hline
\end{tabular}

recurrences due to inadequate excision. Close cooperation between surgeon and pathologist is essential to assure adequate excision. Mohs micrographic surgery may also be a valuable treatment modality. Reports have shown that the local recurrence rate for Mohs micrographic surgery is lower than that for excision (14).

We present the second case of AFX in a patient younger than 30 years of age to be reported in the literature, occurring in a female patient who had no prior exposure to radiation.

\section{CASE PRESENTATION}

A 21-year-old woman presented with a three-month history of an enlarging left nasal alar nodule. The patient reported that the lesion appeared to be acne, yet it failed to respond to topical antibiotics, was increasingly pruritic and continued to grow, occasionally bleeding. The patient had no previous radiation treatment or other significant past medical history.

On physical examination, a nodule measuring $14 \mathrm{~mm}$ in diameter was observed at the left nasal ala (Figure 1). The firm, nontender nodule had overlying telangiectasis and appeared to double in size over three months. The nodule was biopsied and was excised with margins two weeks later. A full-thickness skin graft was used to cover the defect (Figure 2).

A histopathological examination of the excision showed the neoplasm to be circumscribed and composed of hyperchromatic spindle cells and multinucleated giant cells (Figure 3). The specimen did not stain for HMB45, melanoma antigen recognized by $\mathrm{T}$ cells, factor XIIIa, anion exchange protein, CD31 (blood vessels) neuron-specific enolase, S-100 (focal+), actin (blood vessels positive) or melan-A. It stained positive

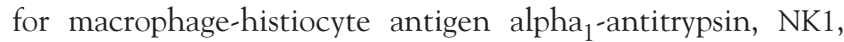
CD68 and alpha ${ }_{1}$-antichymotrypsin (Figure 4). A diagnosis of malignant fibrous histiocytoma (AFX) was made.

\section{DISCUSSION}

AFX is a rare, low-grade sarcoma generally arising on sundamaged or radiation-damaged skin of elderly Caucasian men. Sites most commonly affected are the head and neck, particularly the nose, ears and cheeks. During our search of the literature, it was determined that our patient was the second woman under the age of 30 years to present with AFX of the head and neck. The first patient was a 28-year-old Caucasian woman with a history of radiation in the form of $\mathrm{x}$-ray therapy for acne, in whom the tumour repeatedly defied attempts at local excision and eventually metastasized (15). Our patient had no exposure to radiation and represents the first case in literature of its kind. In two years of clinical follow-up, she has had no local recurrence or lymphadenopathy.

The present patient's original pathological diagnosis was 'atypical spindle cell proliferation', and complete excision was recommended. The diagnosis was made more difficult by the shave biopsy sampling, in which the smaller spindle cells predominated and only a few of those spindle cells stained for CD68. The correct diagnosis was achieved in the excised nodule, in which one side of the lesion had numerous giant histiocyte forms (Figure 4). Additional immunohistochemcial analysis was undertaken.

AFX typically presents on the upper body, mainly the head and neck, because of its predilection for sun-damaged skin.

\section{TABLE 2}

Immunohistochemistry for the clinical differential diagnosis of atypical fibroxanthoma (AFX)

\begin{tabular}{|c|c|c|c|c|c|c|c|c|c|c|c|c|}
\hline $\begin{array}{l}\text { Histology } \\
\text { differential diagnosis }\end{array}$ & NK1/C3 & $\begin{array}{l}\text { Type IV } \\
\text { collagen }\end{array}$ & Desmin & S-100 & Vimentin & Melan-A & $\begin{array}{c}\text { alpha }_{1-} \\
\text { antitrypsin }\end{array}$ & $\begin{array}{l}\text { alpha }{ }_{1} \text {-chymo- } \\
\text { trypsin }\end{array}$ & HAM56 & CD68 & CD99 & Actin \\
\hline AFX & $++^{*}$ & - & - & - & ++ & ++ & + & + & ++ & ++ & + & + \\
\hline MFH & \pm & - & - & - & - & - & \pm & \pm & - & - & - & - \\
\hline Melanoma, spindle cell type & - & - & - & + & + & + & - & - & - & - & - & - \\
\hline SCCA, spindle cell type & - & - & - & - & - & - & - & - & - & - & - & - \\
\hline $\begin{array}{l}\text { Neurothekeoma } \\
\text { (nerve sheath myxoma) }\end{array}$ & \pm & + & - & - & - & - & - & - & - & - & - & - \\
\hline
\end{tabular}

${ }^{*}$ Present case. BCCA Basal cell carcinoma; MFH Malignant fibrous histiocytoma; NK 1 Neurokinin-1; SCCA Squamous cell carcinoma; + Positive; ++ Focally positive; - Negative; \pm Few cells immunoreactive 


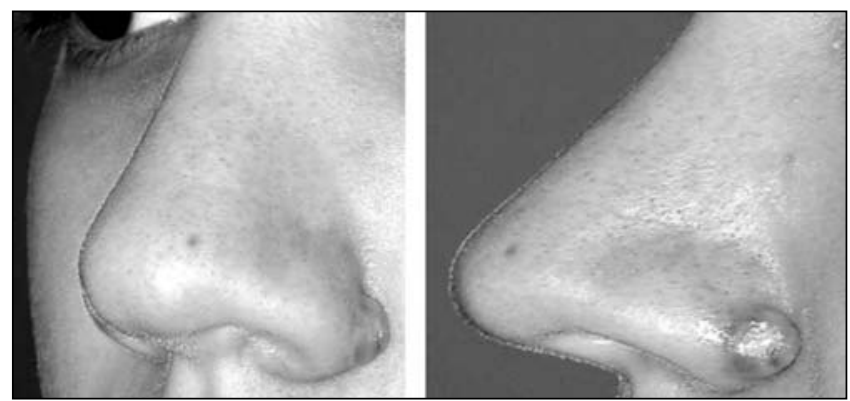

Figure 1) Twenty-one-year-old patient with atypical fibroxanthoma of the left nasal alar

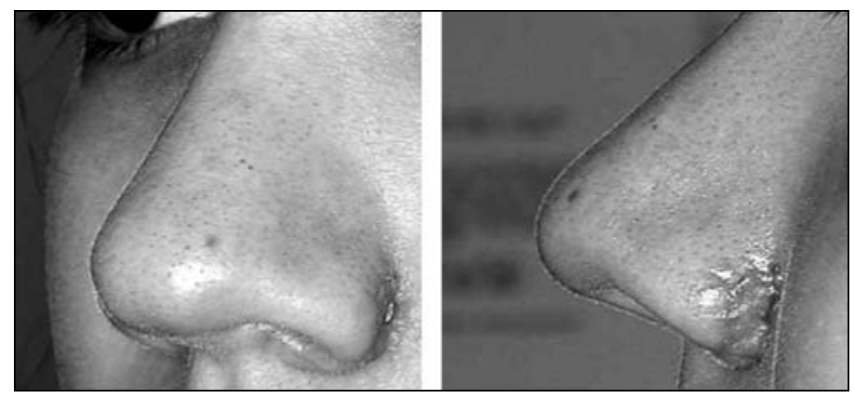

Figure 2) Patient after excision of the atypical fibroxanthoma of the left nasal alar and full thickness skin graft

Most cases of AFX occurring in younger patients present on normal-appearing skin of the limbs or trunk. The correlation between sun-damaged skin and appearance of the tumour suggests the role of ultraviolet radiation in its pathogenesis. It has been reported that the mechanism of ultraviolet damage in eliciting AFX involves mutation of p53 (16). The increased emphasis of tanned skin as a sign of beauty has encouraged increased exposure, including tanning bed use, especially in the younger population, a group less likely to use sunscreen (17). This may be important should other observers note additional cases of AFX in younger patients, especially in those without a history of radiation damage.

The correct diagnosis of this neoplasm is vital to avoiding radical excision. These neoplasms have similar clinical presentations to squamous cell carcinoma, basal cell carcinoma, malignant fibrous histiocytoma and malignant melanoma. Furthermore, each of these same neoplasms in skin may have a component of or even a predominance of spindle cells, and thus be confused histopathologically.

As demonstrated by the present case report, the possibility of AFX should be considered in the setting of spindle cell

\section{REFERENCES}

1. Helwig EB. Atypical fibroxanthoma. Proceedings of the 18th Annual Tumor Seminar of San Antonio Society of Pathologists, 1961. Tex State J Med 1963;59:664. (Abst)

2. Helwig EB, May D. Atypical fibroxanthoma of the skin and metastasis. Cancer 1986;57:368-76.

3. Weiss SW, Goldblum JR. Malignant fibrohistiocytic tumors. In: Strauss M, ed. Enzinger and Weiss's Soft Tissue Tumors, 4th edn. St Louis: Mosby, 2001:535-69.

4. Fretzin EB, Helwig EB. Atypical fibroxanthoma of the skin. A clinicopathologic study of 140 cases. Cancer 1973;31:1541-52.

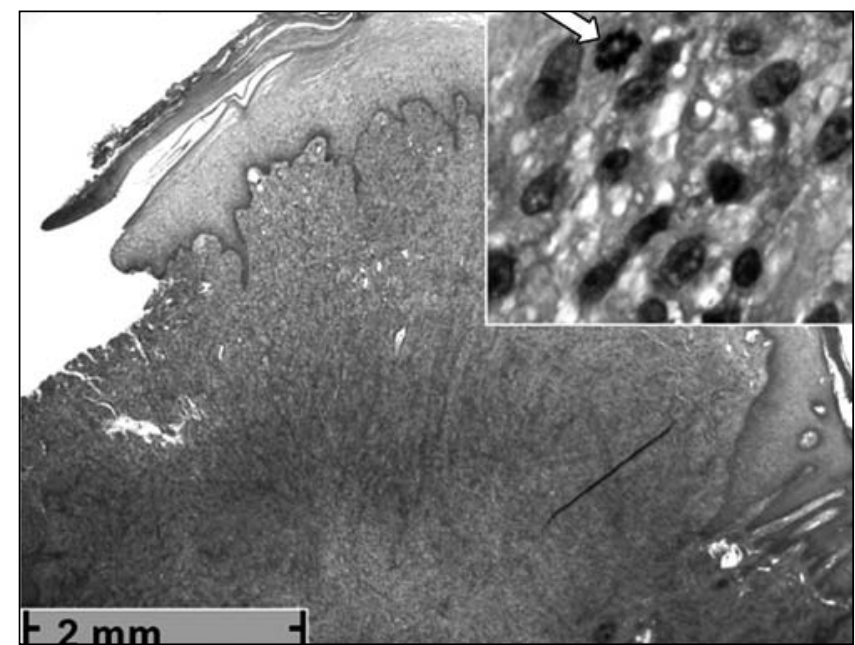

Figure 3) Pleomorphic spindle: Domed nodule composed of hyperchromic and pleomorphic vacuolated spindle cells. Arrow indicates mitosis (hematoxylin and eosin composite, original magnification $\times 2$ [inset $\times 40]$ )

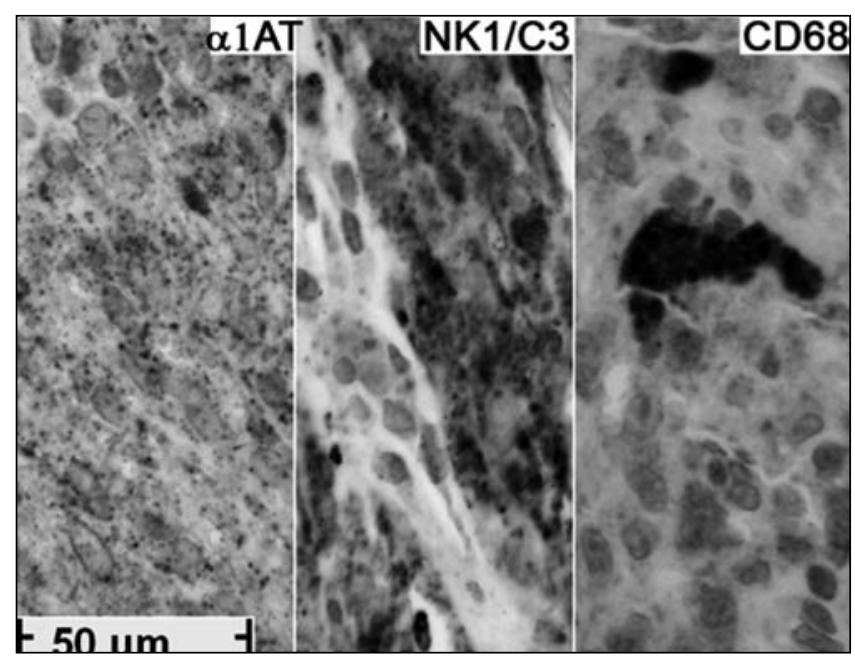

Figure 4) Composite image of immunohistochemical stains (histiocyte

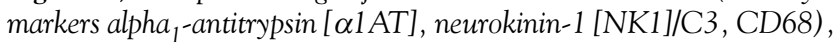
'giant' cell at right, original magnification $\times 40$

neoplasms, especially when multinucleated 'giant' histiocytes are recognized, regardless of patient age.

ACKNOWLEDGEMENTS: This study was supported by an Empire Clinical Research Investigators Program Award (to MMM). We gratefully acknowledge Dr Diana Sun MD for referring the patient to us for care. 
8. Tamada S, Ackerman AB. Dermatofibroma with monster cells. Am J Dermatopathol 1987;9:380-7.

9. Dettrick A, Strutton G. Atypical fibroxanthoma with perineural or intraneural invasion: Report of two cases. J Cutan Pathol 2006;33:318-22

10. Kroe DJ, Pitcock JA. Atypical fibroxanthoma of the skin. Report of ten cases. Am J Clin Pathol 1969;51:487-92.

11. Farley R, Ratner D. Diagnosis and management of atypical fibroxanthoma. Skinmed 2006;5:83-6.

12. Heintz PW, White CR Jr. Diagnosis: Atypical fibroxanthoma or not? Evaluating spindle cell malignancies on sun damaged skin: A practical approach. Semin Cutan Med Surg 1999;18:78-83.

13. Starink TH, Hausman R, Van Delden L, Neering H. Atypical fibroxanthoma of the skin. Presentation of 5 cases and a review of the literature. Br J Dermatol 1977;97:167-77.

14. Davis JL, Randle HW, Zalla MJ, Roenigk RK, Brodland DG.

A comparison of Mohs micrographic surgery and wide excision for the treatment of atypical fibroxanthoma. Dermatol Surg 1997;23:105-10.

15. Jacobs DS, Edwards WD, Ye RC. Metastatic atypical fibroxanthoma of skin. Cancer 1975 Feb;35:457-63.

16. Dei Tos AP, Mastero R, Doglioni C, et al. Ultraviolet-induced p53 mutations in atypical fibroxanthoma. Am J Pathol 1994;145:11-7.

17. Alan CG, Graham C, Susan O, et al. Use of sunscreen, sunburning rates, and tanning bed use among more than 10000 US children and adolescents. Pediatrics 2002;109:1009-14. 